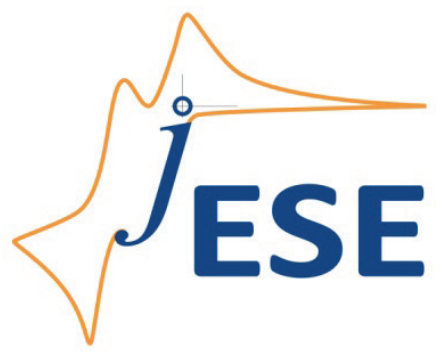

Open Access : : ISSN 1847-9286

www.jESE-online.org

Original scientific paper

\title{
In-situ activated hydrogen evolution by molybdate addition to neutral and alkaline electrolytes
}

JOHN GUSTAVSSON ${ }^{\bowtie}$, CHRISTINE HUMMELGÅRD*, JOAKIM BÄCKSTRÖM*, INGER ODNEVALL WALLINDER**, SEIKH MOHAMMAD HABIBUR RAHMAN***, GÖRAN LINDBERGH, STEN ERIKSSON*** and ANN CORNELL

Applied Electrochemistry, School of Chemical Science and Engineering, KTH Royal Institute of Technology, SE-100 44 Stockholm, Sweden

*Department of Natural Sciences, Engineering and Mathematics, Mid Sweden University, SE-851 70 Sundsvall, Sweden

**Department of Surface and Corrosion Science, KTH Royal Institute of Technology, SE-100 44 Stockholm, Sweden

***Department of Chemical and Biological Engineering, Chalmers University of Technology, SE-412 96 Gothenburg, Sweden

Corresponding Author: E-mail: johngus@kth.se; Tel.: +46-87908171

Received: May 15, 2012; Published: August 30, 2012

\begin{abstract}
Activation of the hydrogen evolution reaction (HER) by in-situ addition of Mo(VI) to the electrolyte has been studied in alkaline and $\mathrm{pH}$ neutral electrolytes, the latter with the chlorate process in focus. Catalytic molybdenum containing films formed on the cathodes during polarization were investigated using scanning electron microscopy (SEM), energy-dispersive $X$-ray analysis (EDS), X-ray photoelectron spectroscopy (XPS), and $X$-ray fluorescence (XRF). In-situ addition of $M o(V I)$ activates the HER on titanium in both alkaline and neutral electrolytes and makes the reaction kinetics independent of the substrate material. Films formed in neutral electrolyte consisted of molybdenum oxides and contained more molybdenum than those formed in alkaline solution. Films formed in neutral electrolyte in the presence of phosphate buffer activated the HER, but were too thin to be detected by EDS. Since molybdenum oxides are generally not stable in strongly alkaline electrolyte, films formed in alkaline electrolyte were thinner and probably co-deposited with iron. A cast iron-molybdenum alloy was also investigated with respect to activity for HER. When polished in the same way as iron, the alloy displayed a similar activity for HER as pure iron.
\end{abstract}

\section{Keywords}

Molybdate, molybdenum dioxide, electrodeposition, electrolysis 


\section{Introduction}

Sodium chlorate is produced in an energy-intensive process where sodium chloride is oxidized into sodium chlorate with hydrogen gas as a product (reaction 1). Industrial, dimensionally stable, anodes $\left(D^{\circ} A^{\circledR}\right.$ ) are used as anodes while the cathodes are normally made from low-alloyed carbon steel or titanium. Steel cathodes corrode, which shortens their lifetime and may result in short circuiting of the electrolysis cells and furthermore corrosion products that are formed can contaminate the product. Steel cathodes have overpotentials of around $800 \mathrm{mV}$ for hydrogen evolution (reaction 2) [1].

$$
\begin{aligned}
& \mathrm{NaCl}+3 \mathrm{H}_{2} \mathrm{O} \rightarrow \mathrm{NaClO}_{3}+3 \mathrm{H}_{2} \\
& 2 \mathrm{H}_{2} \mathrm{O}+2 \mathrm{e}^{-} \rightarrow \mathrm{H}_{2}+2 \mathrm{OH}^{-}
\end{aligned}
$$

Titanium cathodes are more corrosion resistant than steel cathodes. Drawbacks are that titanium hydride forms over time and that Ti shows even higher overpotentials compared to steel. The electric energy used for electrolysis accounts to up to $80 \%$ of the variable production cost of chlorate, and with rising costs for electricity a reduction of the cathode overpotential is of utmost importance. Another major concern is the search for an alternative to the carcinogenic $\mathrm{Cr}(\mathrm{VI})$ electrolyte additive. At present, $\mathrm{Cr}(\mathrm{VI})$ is necessary to obtain high current efficiency in the process. During operation $\mathrm{Cr}(\mathrm{VI})$ is electrodeposited on the cathode, forming a film of chromium hydroxide that hinders the electroreduction of chlorate and hypochlorite $\left(\mathrm{HClO}\right.$ and $\left.\mathrm{ClO}^{-}\right)$, an intermediate in the chlorate process [2]. Chromate also functions as a buffer to keep the electrolyte $\mathrm{pH}$ between 5.9 and 6.7, which is optimal for the process [3].

Many attempts have been made to replace the cathode material in the chlorate process by electrodes with coatings containing ruthenium compounds as electrocatalyst, see for example Refs [4] and [5]. Although they show a high catalytic activity for hydrogen evolution, their long-term stability has not yet been resolved. The chlorate cathode is subject to stringent requirements- it should be stable both during vigorous hydrogen evolution and during production stops in the corrosive electrolyte. Also, its corrosion products should not catalyze the decomposition of hypochlorite in the bulk electrolyte and cathodes containing for example nickel or cobalt are therefore excluded [1].

In-situ activation, the addition of a compound to the electrolyte that enhances the electrocatalytic properties of the cathodes, has several advantages over the above mentioned cathode replacement - fast, simple implementation in existing plants, a constant renewal of the cathode surface and the possibility to use substrate materials that can survive the harsh conditions in the chlorate process.

Molybdenum (VI) has shown some promising features as an in-situ activator for hydrogen evolution, both in chlorate electrolyte [6][7] and in strongly alkaline solutions [8]-[13]. What makes it even more interesting for the chlorate application is the ability of Mo-containing films formed in-situ to suppress cathodic oxygen reduction [14] (and thereby also possibly the reduction of hypochlorite). Molybdenum (VI) is regarded as an environmentally friendly alternative to $\mathrm{Cr}(\mathrm{VI})$ in corrosion applications [14].

Li et al. [6] have investigated the possibility to replace $\mathrm{Cr}(\mathrm{VI})$ with $\mathrm{Mo}(\mathrm{VI})$ in the chlorate electrolyte. They concluded that $\mathrm{Mo}(\mathrm{VI})$ addition decreased the overpotential for hydrogen evolution by $100-130 \mathrm{mV}$ on steel cathodes, that the two compounds had comparable buffer capacity, and that the Mo(VI) addition increased the levels of unwanted oxygen in the cell gas. Later studies [7] have indicated that the effect on oxygen levels depends on the Mo(VI) 
concentration, and that low concentrations of $\mathrm{MoO}_{3}\left(1-10 \mathrm{mg} \mathrm{dm}^{-3}(7-70 \mu \mathrm{M} \mathrm{Mo}(\mathrm{VI}))\right)$ can activate the hydrogen evolution reaction (HER) without any increased oxygen production. In the absence of $\mathrm{Cr}(\mathrm{VI})$, such low $\mathrm{Mo}(\mathrm{VI})$ levels require an additional buffer such as phosphate to stabilize the electrolyte $\mathrm{pH}$. These studies in chlorate electrolyte did not include any surface analyses of possible electrode films.

At strongly alkaline conditions, $30 \mathrm{wt} . \% \mathrm{KOH}$ at $70^{\circ} \mathrm{C}$ [8]-[13], it was found that films containing molybdenum and iron, the latter present as an impurity in the electrolyte, co-deposited on the metal cathodes and resulted in hydrogen overpotentials at $-1 \mathrm{kA} \mathrm{m}^{-2}$ that were virtually independent of the substrate material. Typically, after $17 \mathrm{~h}$ of polarization in the presence of $4 \mathrm{mM} \mathrm{Mo}(\mathrm{VI})$, the observed overpotentials for hydrogen evolution on metal substrates of $\mathrm{Co}, \mathrm{Cu}$, $\mathrm{Fe}, \mathrm{Mo}, \mathrm{Nb}, \mathrm{Ni}, \mathrm{Pd}, \mathrm{Pt}, \mathrm{V}, \mathrm{W}$, and $\mathrm{Zr}$ varied within $40 \mathrm{mV}$ compared to a $650 \mathrm{mV}$ variation in the absence of $\mathrm{Mo}(\mathrm{VI})$ [11]. In the absence of electrolyte impurities such as iron, no molybdenumcontaining deposits were found [13]. Elemental molybdenum cannot be electrodeposited from aqueous electrolytes, but as alloys with iron group metals [14] or as molybdenum oxides [14].

The ability of electrolyte additions of $\mathrm{Mo}(\mathrm{VI})$ to suppress the cathodic oxygen reduction has been investigated on copper [14]. The inhibiting effect was most efficient at $\mathrm{pH} 8.2$ and ended at $\mathrm{pH} 11$, probably due to differences in the cathodic surface films formed in the electrolytes of varying $\mathrm{pH}$. In particular the oxide $\mathrm{MoO}_{2}$, a probable constituent of a cathode film formed by electroreduction of $\mathrm{Mo}(\mathrm{VI})$, has limited stability in alkaline solutions [14]4,[16]. The study did not include surface analyses of cathode films that formed.

The aim of the present study is to demonstrate how $\mathrm{Mo}(\mathrm{VI})$ additions to the electrolyte can activate the HER. As the properties of the cathode films formed depend on the electrolyte $\mathrm{pH}$, films formed at $\mathrm{pH} 6.5$ (relevant for the chlorate process) have been compared to films formed at alkaline conditions, $1 \mathrm{M} \mathrm{NaOH}$. Polarization curves for hydrogen evolution have been combined with surface analyses by scanning electron microscopy (SEM), energy-dispersive X-ray analysis (EDS), X-ray photoelectron spectroscopy (XPS), X-ray fluorescence (XRF), optical microscopy and Xray diffraction (XRD). Interesting results on films of co-precipitated Mo and Fe initiated the casting of iron-molybdenum alloy. This cast material could potentially be polished to a smooth surface and allow electrocatalytic effects to be separated from effects of increased surface area, which can be difficult when studying electrodeposited films.

The long-term goal is a chromate-free chlorate process with stable, energy-efficient cathodes. Selectivity aspects of replacing $\mathrm{Cr}(\mathrm{VI})$ with $\mathrm{Mo}(\mathrm{VI})$ will be presented in a later communication.

\section{Experimental}

\section{Electrochemistry}

The working electrodes were rotating-disc electrodes (RDEs) of commercially pure titanium $(\varnothing 4 \mathrm{~mm})$, platinum $(\varnothing 4 \mathrm{~mm})$, gold $(\varnothing 4 \mathrm{~mm})$, molybdenum $(\varnothing 6 \mathrm{~mm})$, iron $(\varnothing 5 \mathrm{~mm})$, and iron-molybdenum alloy $(\varnothing 6 \mathrm{~mm})$, all embedded in Teflon, and a titanium RDE $(\varnothing 11.3 \mathrm{~mm})$ in a titanium holder shielded by epoxy and silicon tubing. The RDEs were run with an electrode rotator Model 616 from Pine Instrument Company. A platinum grid was used as the counter electrode and the reference electrodes were a red rod electrode (REF201 from Radiometer) with saturated $\mathrm{KCl}$, a saturated calomel electrode (REF401 from Radiometer), or an $\mathrm{Hg} / \mathrm{HgO} / 1 \mathrm{M} \mathrm{KOH}$ electrode (XR400 and XR440 from Radiometer), all connected to a Luggin capillary.

The platinum RDE was polished with alumina paste (Alpha micropolish No. 1 C, particle size $1.0 \mu \mathrm{m}$, from Buehler), washed with MilliQ water, cleaned in an ultrasonic bath with acetone and 
thoroughly washed with MilliQ water. The molybdenum, iron, iron-molybdenum alloy and titanium RDEs were polished with grit $4000 \mathrm{SiC}$ grinding paper. When the experiments began, the iron electrode was immersed in the electrolyte under cathodic polarization to avoid uncontrolled corrosion.

The electrolytes were made from MilliQ water; sodium chloride, sodium hydroxide, hydrochloric acid, iron(III) chloride hexahydrate, sodium molybdate dihydrate, sodium dihydrogen phosphate, all from Merck, and of pro analysi grade. When we use the terms "phosphate concentration" or "total phosphate concentration", we are referring to the sum of phosphate species, for example $\left[\mathrm{PO}_{4}{ }^{3-}\right]_{\mathrm{tot}}=\left[\mathrm{H}_{3} \mathrm{PO}_{4}\right]+\left[\mathrm{H}_{2} \mathrm{PO}_{4}{ }^{-}\right]+\left[\mathrm{HPO}_{4}{ }^{2-}\right]+\left[\mathrm{PO}_{4}{ }^{3-}\right]$. In the present study, we excluded $\mathrm{NaClO}_{3}$ from the electrolytes as trace amounts of $\mathrm{Cr}(\mathrm{VI})$ present in the chlorate salt may form cathodic surface films that influence the kinetics for the HER. As model systems, either $2 \mathrm{M} \mathrm{NaCl}$ (around neutral $\mathrm{pH}$ ) or $1 \mathrm{M} \mathrm{NaOH}\left(\mathrm{pH} \approx 13,70^{\circ} \mathrm{C}\right)$ were used. Nitrogen purging was used $15 \mathrm{~min}$ prior and during the electrochemical experiments to deaerate the electrolyte

Galvanostatic polarization experiments were recorded with a PAR 273A potentiostat controlled by LabView. Each point was recorded for 15 seconds and a current interrupt technique [17] was used for the IR-correction. Each experiment was repeated at least once with good repeatability.

Current efficiency measurements were made to evaluate how large a proportion of the applied current that was related to this side reaction. A divided cell was used [23] with stationary titanium electrodes and electrolytes of $2 \mathrm{M} \mathrm{NaCl}$ with and without $100 \mathrm{mM} \mathrm{Mo(VI)} \mathrm{polarized} \mathrm{at}-3 \mathrm{kA} \mathrm{m}^{-2}$ at $70^{\circ} \mathrm{C}$. Both an electrolyte of $2 \mathrm{M} \mathrm{NaCl}, \mathrm{pH} 6.5$ and an alkaline electrolyte containing $2 \mathrm{M} \mathrm{NaCl}$, $1 \mathrm{M} \mathrm{NaOH}$ were investigated. This relatively high concentration was chosen to see any effect on current efficiency more clearly.

\section{Surface analysis}

RDEs polarized for SEM measurements were removed from the electrolyte without breaking the polarization current and were carefully dipped into MilliQ water for a few seconds to remove excess electrolyte. For the SEM analysis, LEO 1450 EP SEM and Zeiss EVO 50 SEM with EDS were used with accelerator voltages of $20 \mathrm{kV}$. XRF measurements were performed using a Niton XLT898 instrument with an accelerator voltage of $35 \mathrm{kV}$ and a silver anode.

The molybdenum iron alloy sample was molded in epoxy and polished in four steps: (i) SiC grit 220 grinding paper, (ii) $9 \mu \mathrm{m}$ diamond suspension, (iii) $3 \mu \mathrm{m}$ diamond suspension, and (iv) $0.04 \mu \mathrm{m}$ colloid silica suspension. All polishing material was purchased from Struers. The polished sample was metallographically etched in a freshly prepared 1:1 mixture of $10 \mathrm{wt} \% \mathrm{KOH}(\mathrm{aq})$ and $10 \mathrm{wt} . \% \mathrm{~K}_{3} \mathrm{Fe}(\mathrm{CN})_{6}(\mathrm{aq})$ [18][20] and inspected using a Zeiss Axiotech Vario optical microscope with a Kappa digital camera.

XPS compositional analyses were performed using an UltraDLD spectrometer (Kratos Analytical, Manchester, UK) with a monochromatic Al x-ray source (1486.5 eV) on two separate areas of approximately $700 \times 300 \mu \mathrm{m}$ for each sample. Binding energies are given as the average of the peak positions of the two areas. The chamber pressure was approximately $2 \times 10^{-9}$ mbar during analysis. Wide spectra (pass energy of $160 \mathrm{eV}$ ) and core level high resolution spectra (20 eV pass energy) were acquired for Mo 3d, Ti 2p, O 1s, and C 1s. All binding energies were corrected by setting the hydrocarbon C1s peak to $285.0 \mathrm{eV}$.

XRD measurements were carried out at ambient temperature using a Bruker AXS D8 ADVANCE VARIO powder diffractometer. The sample disc surface was polished gradually using grit 500, 1000, 2400 to $4000 \mathrm{SiC}$ paper and rinsed with acetone in an ultrasonic cleaner. The diffractometer was operated with $\mathrm{Cu} K_{\alpha}$ radiation generated at $40 \mathrm{kV}$ acceleration voltage and $40 \mathrm{~mA}$ current. High 
resolution X-ray diffraction patterns were collected in order to identify the phases using monochromatic $\mathrm{Cu}_{\alpha 1}(1.5406 \AA$ ) radiation obtained with a germanium primary monochromator, using a solid-state rapid LynxEye detector in a Bragg-Brentano geometry. Scans were performed for the $2 \theta$ range $20-100^{\circ}$, with a step size of $0.0092^{\circ}$ and $3.9 \mathrm{~s}$ collection time per step. The resulting pattern was imported into the evaluation software package DIFFRACow EVA with SEARCH, where phases were identified, after background subtraction with the aid of the ICDD database [21].

\section{Iron-molybdenum alloy casting}

Iron pieces $99.99 \%$ and molybdenum slug $6.35 \mathrm{~mm}$ diameter $\times 6.35 \mathrm{~mm}$ length, $99.95 \%$ were ordered from Alfa Aesar for the alloy production. The alloy was melted in a casting form with 40 $\mathrm{mm} \times 40 \mathrm{~mm}$ sides and the mass was $500 \mathrm{~g}$ total alloy with nominal composition 67 at.\% (54.2 wt.\%) iron and 33 at.\% (45.8 wt.\%) molybdenum by Swerea KIMAB AB, Stockholm, Sweden. A small part of the molybdenum formed a separate layer and was later removed. Since the melting point increases with increasing molybdenum content [22] alloys with higher molybdenum content could not be cast. According to Laser Ablation Inductively Coupled Plasma Mass Spectrometry (LA-ICP-MS) analysis, the alloy produced had a composition of 72.4 at.\% (60.4 wt.\%) iron and 27.6 at.\% (39.5 wt.\%) molybdenum.

\section{Results and discussion}

The section is organized as follows: first, we present the electrochemical measurements showing an in-situ activation effect for HER of adding $\mathrm{Mo}(\mathrm{IV})$ salt to $\mathrm{NaCl}$ and $\mathrm{NaOH}$ electrolytes. We also investigated how addition of phosphate buffer modified the results. In the next subsection, we present our results from surface analyses of the films formed during electrolysis in the preceding subsection. In the final subsection, we address the issue of synergetic effects when combining iron and molybdenum by investigating the electrochemistry of a well-characterized cast alloy sample during HER.

\section{In-situ activation}

In Figure 1, polarization curves for hydrogen evolution are shown for molybdenum and titanium rotating disc electrodes in $2 \mathrm{M} \mathrm{NaCl}$ at $\mathrm{pH} 6.5$ in both absence and presence of $4 \mathrm{mM} \mathrm{Mo}(\mathrm{VI})$. Without $\mathrm{Mo}(\mathrm{VI})$ in the electrolyte, both titanium and molybdenum were less active than iron with Tafel slopes of $-340 \mathrm{mV} \mathrm{dec} c^{-1}$ and $-180 \mathrm{mV} \mathrm{dec}{ }^{-1}$, respectively. When reversing the polarization curves (not shown), titanium showed a more active electrode, indicating non-stationary conditions. In the presence of $\mathrm{Mo}(\mathrm{VI})$, the two substrates gave similar potentials for the HER and Tafel slopes in the range -170 to $-180 \mathrm{mV} \mathrm{dec}{ }^{-1}$. At technical current densities (between -2 and $-3 \mathrm{kA} \mathrm{m}^{-2}$ ), the in-situ activated electrodes were approximately as active as iron. Thus, as found earlier for strongly alkaline conditions [11], the addition of $\mathrm{Mo}(\mathrm{VI})$ changed the electrode kinetics and seemed to make the cathode potential relatively independent of the substrate material.

The Mo(VI) compounds in the electrolyte may be cathodically reduced to, for example, Mo(IV) species. Current efficiency measurements, made under vigorous magnetic stirring and hydrogen gas bubble generation, showed current efficiencies for hydrogen production of 95-100\% regardless of whether $100 \mathrm{mM} \mathrm{Mo(VI)} \mathrm{was} \mathrm{present} \mathrm{or} \mathrm{not} \mathrm{and} \mathrm{irrespective} \mathrm{of} \mathrm{electrolyte} \mathrm{pH}$. Any reduction of Mo-species was thus only a minor part of the total applied current and the altered kinetics were not due to a major change in electrode reaction from hydrogen evolution to Mo(VI) reduction. Again, addition of $\mathrm{Mo}(\mathrm{VI})$ did not lead to a significant loss in current efficiency, which is important for the energy efficiency of the process. 


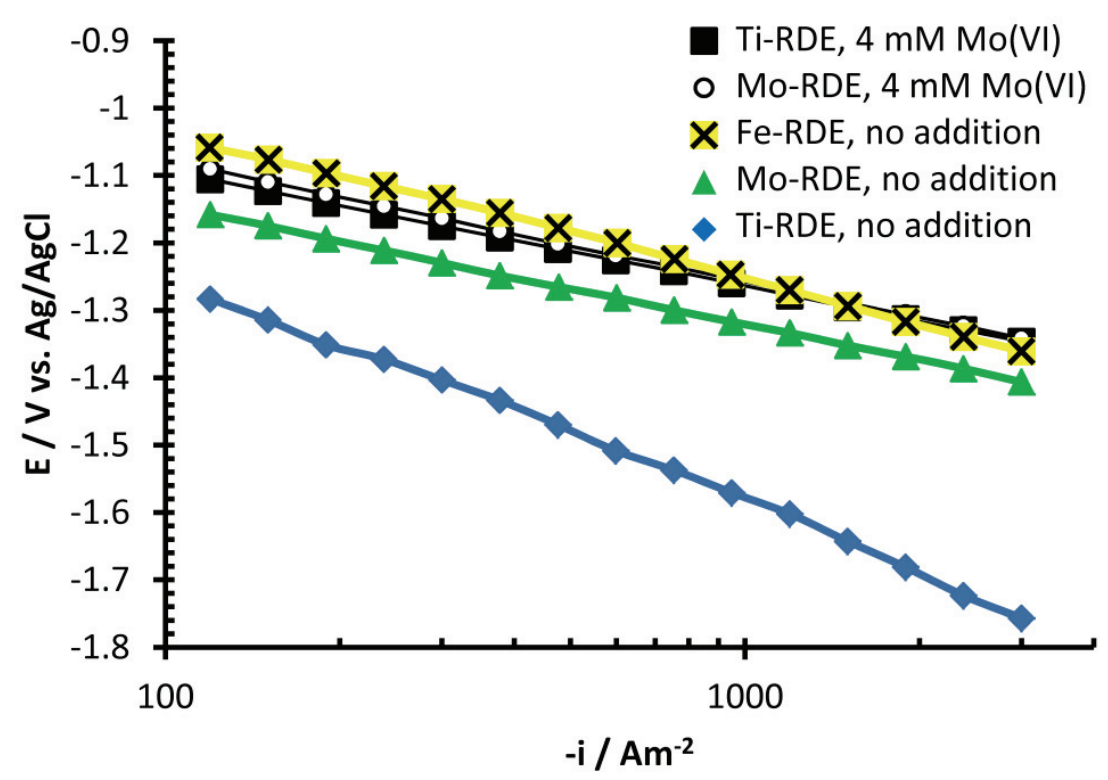

Figure 1. IR-corrected polarization curves recorded in $2 \mathrm{M} \mathrm{NaCl}, \mathrm{pH} \approx 6.5,70^{\circ} \mathrm{C}$ at a rotation rate of $5000 \mathrm{rpm}$. All polarization curves were recorded in the anodic direction. The electrodes were pre-polarized at $-3 \mathrm{KA} \mathrm{m}^{-2}$ for 15 min prior to the polarization curves.

Electrolysis in electrolytes of near neutral $\mathrm{pH}$ may benefit from the addition of buffers, as is the case of chlorate electrolysis. Mo(VI) can act as a $\mathrm{pH}$ buffer with a $\mathrm{pK}_{\mathrm{a}}$ value of 6.0 [5], but an additional buffer is required if low $\mathrm{Mo}(\mathrm{VI})$ concentrations are desired. Phosphoric acid, dihydrogen phosphate and hydrogen phosphate with $\mathrm{pK}_{\mathrm{a}}$ values of $2.15,7.20$ and 12.38 at $25^{\circ} \mathrm{C}$ [23] could for example be used. We have investigated the impact of addition of $40 \mathrm{mM}$ of total phosphate to the $\mathrm{Mo}(\mathrm{VI})$-containing electrolyte using both $\mathrm{Mo}$ and Ti electrodes. As seen in Figure 2, there were no negative effects of phosphate addition on the Mo(VI) activation of the HER at high current densities. There was even a positive effect on the cathode potential at lower current densities. The in-situ activation by phosphate is a buffer effect, seen as an increased limiting current for $\mathrm{H}_{2} \mathrm{PO}_{4}{ }^{-}$ and/or $\mathrm{HPO}_{4}{ }^{2-}$, that buffers the surface $\mathrm{pH}$ and possibly electrochemically deprotonates at the cathode surface [24]. Note that the polarization curves for the Mo-activated hydrogen evolution in Figures 1 and 2 show no limiting currents, indicating a different activation mechanism than for phosphate. In the case of $\mathrm{Mo}(\mathrm{VI})$-addition, a catalytic film was probably formed while the phosphate species resulted in an activation by replacing water as a reactant in the HER. To verify the role of $\mathrm{Mo}(\mathrm{VI})$, the following experiment was performed: two titanium electrodes were prepolarized for $30 \mathrm{~min}$ at $-3 \mathrm{kA} \mathrm{m}^{-2}$ and $3000 \mathrm{rpm}$ in $2 \mathrm{M} \mathrm{NaCl}$ at $70^{\circ} \mathrm{C}$ and $\mathrm{pH} 6.5$ with and without the addition of $100 \mathrm{mM} \mathrm{Mo(VI)}$. The electrodes were then rinsed and transferred to an $\mathrm{Mo}(\mathrm{VI})$ free electrolyte of identical composition, and the electrode potentials were measured at $-3 \mathrm{kA} \mathrm{m}^{-2}$. Electrodes pre-polarized in an Mo(VI)-containing electrolyte had about $200 \mathrm{mV}$ lower overpotential for hydrogen evolution compared with electrodes pre-polarized in the absence of $\mathrm{Mo}(\mathrm{VI})$. These results indicate that the activation of hydrogen evolution relates to a catalytic film formed on the cathode surface and not primarily to a mass-transport controlled deprotonation of electrolyte species, as found earlier in $\mathrm{pH}$-neutral electrolytes for catalysis of the HER by for example phosphate [24] or yttrium ions [25]. Since the $100 \mathrm{mMMo}(\mathrm{VI})$ was present in the electrolyte, the overpotential for HER increased with time after the initial activation. At the end of the 30 min period, the activation was only $100 \mathrm{mV}$ compared to titanium without addition of $\mathrm{Mo}(\mathrm{VI})$ to the electrolyte (without IR-correction the electrode with molybdenum -containing film with time became even worse than the pure titanium). When electrodes with deposited 
molybdenum-containing films were transferred to a $\mathrm{Mo}(\mathrm{VI})$-free electrolyte, the overpotential decreased again. Obviously, there is an optimal Mo(VI) concentration to achieve the best activation of the HER. In this study, we have chosen to work mostly with additions of $4 \mathrm{mM}$ $\mathrm{Mo}(\mathrm{VI})$, the same concentration as Huot and Brossard [9] recommend for alkaline water electrolysis. In Figure 1, the observed activation of HER at $400 \mathrm{mV}$ on titanium with $4 \mathrm{mM} \mathrm{Mo(VI)}$ is significantly higher than the activation at $100 \mathrm{mV}$ with $100 \mathrm{mM} \mathrm{Mo(VI)} \mathrm{(not} \mathrm{shown).}$

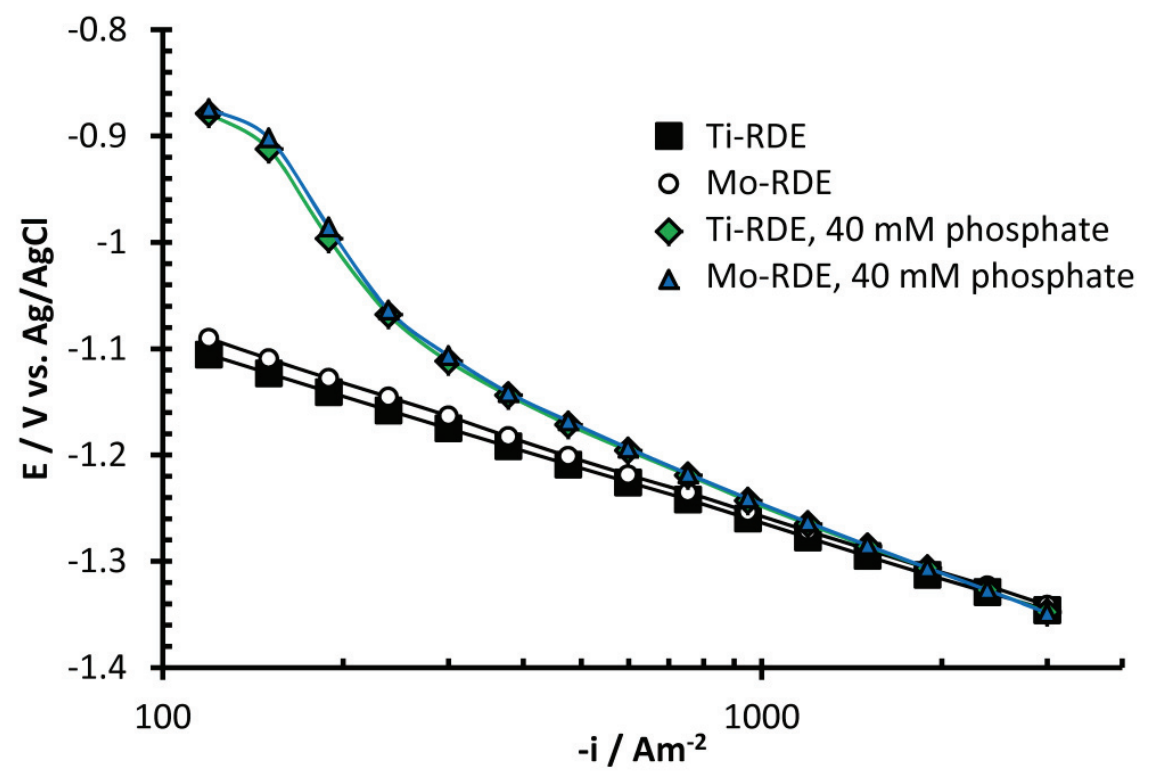

Figure 2. IR-corrected polarization curves recorded in $2 \mathrm{M} \mathrm{NaCl}, 4 \mathrm{mM} \mathrm{Mo}(\mathrm{VI}), \mathrm{pH} \approx 6.5,70^{\circ} \mathrm{C}$ at a rotation rate of $5000 \mathrm{rpm}$. All polarization curves were recorded in the anodic direction. The electrodes were pre-polarized at $-3 \mathrm{kA} \mathrm{m}^{-2}$ for $15 \mathrm{~min}$ prior to the polarization curves.

As already mentioned, electrodeposited $\mathrm{MoO}_{2}$ is not stable at alkaline conditions [14][16]. To investigate if this would affect activation for hydrogen evolution, cathodic polarization curves were recorded in an electrolyte of $1 \mathrm{M} \mathrm{NaOH}$. As can be seen in Figure 3, without additions of $\mathrm{Mo}(\mathrm{VI})$ the Tafel slopes were $-160 \mathrm{mV} \mathrm{dec}^{-1}$ for titanium as cathode material and $-100 \mathrm{mV} \mathrm{dec}^{-1}$ for molybdenum. After polarization in the presence of $4 \mathrm{mM} \mathrm{Mo(VI)}$, the Tafel slopes were the same for the two electrode substrates, $-130 \mathrm{mV} \mathrm{dec}{ }^{-1}$. Furthermore, the electrodes were more active in the presence of $\mathrm{Mo}(\mathrm{VI})$ in the electrolyte. Both titanium and molybdenum substrates showed a similar potential for HER. When comparing the results in Figure 1 at near neutral $\mathrm{pH}$ with Figure 3 at $1 \mathrm{M} \mathrm{NaOH}$ and the data at $30 \mathrm{wt} . \% \mathrm{KOH}, 80^{\circ} \mathrm{C}$, in ref [11], the activation seems to follow the same pattern irrespective of the electrolyte $\mathrm{pH}$ although different films were formed. The addition of $\mathrm{Mo}(\mathrm{VI})$ to the electrolyte results in film formation on the cathode surfaces and the films, which, rather than the substrate, will to a large extent determine HER activity.

\section{Surface characterization}

In Figure 4, secondary electron mode SEM images are shown of titanium electrodes that had been polarized with and without $\mathrm{Mo}(\mathrm{VI})$ in the electrolyte. A film, that contained molybdenum according to EDS data, can be seen after polarization in the presence of $\mathrm{Mo}(\mathrm{VI})$ as well as crystals of high Mo content and of $\mathrm{Na}$ and $\mathrm{Cl}$. In Figure 5, back-scatter mode SEM images show titanium electrodes polarized with $\mathrm{Mo}(\mathrm{VI})$ in both absence and presence of $20 \mathrm{mM}$ total phosphate. 


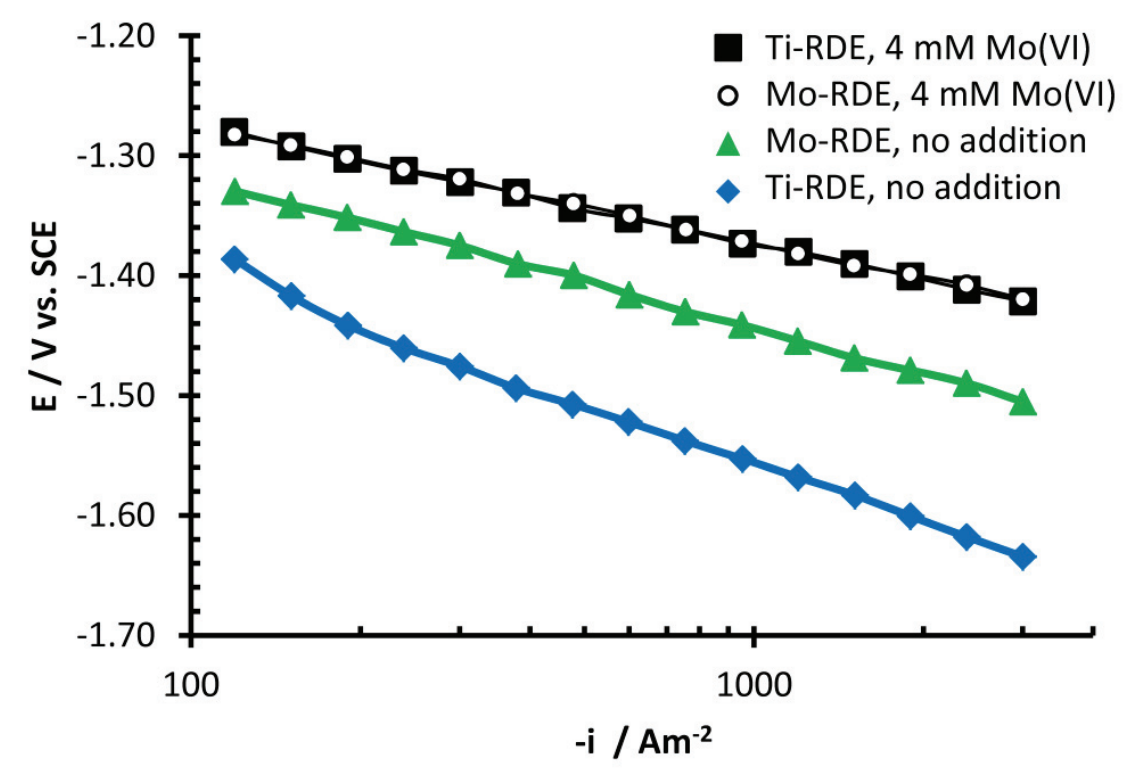

Figure 3. IR-corrected polarization curves recorded in $1 \mathrm{M} \mathrm{NaOH}, 70^{\circ} \mathrm{C}$ at a rotation rate of $5000 \mathrm{rpm}$. All polarization curves were recorded in the anodic direction. The electrodes were pre-polarized at $-3 \mathrm{kA} \mathrm{m}^{-2}$ for 15 min prior to the polarization curves.

The molybdenum-containing film can be seen only on the electrode polarized in the absence of phosphate. No molybdenum-containing film was observed when the total phosphate concentration was varied between $10 \mathrm{mM}$ and $40 \mathrm{mM}$. This may be due to competitive adsorption of molybdate and phosphate, which has earlier been found on gibbsite in soil [26]. This may explain why molybdenum could not be detected with EDS on the titanium surface in the presence of phosphate. Another possible explanation is the formation of some metal phosphate interfering with the film formation. Activation of the HER by $\mathrm{Mo}(\mathrm{VI})$ was also found in the presence of phosphate, as shown in Figure 2. Obviously, a catalytic film was formed which dissolved, detached or was too thin to be detected by EDS.

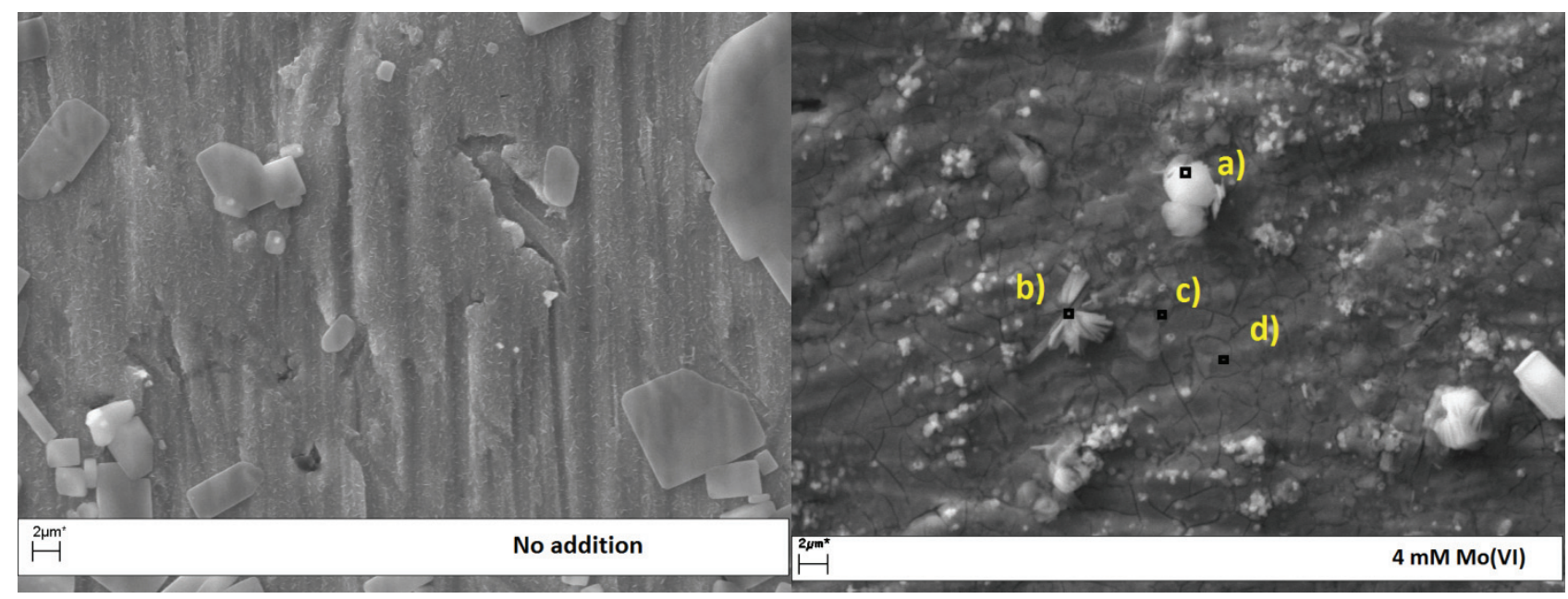

Figure 4. SEM images on Ti-RDEs polarized for 30 min at $-3 \mathrm{kA} \mathrm{m}^{-2}$ in $2 \mathrm{M} \mathrm{NaCl}, \mathrm{pH} \approx 6.5$ and $70^{\circ} \mathrm{C}$ with and without $4 \mathrm{mM} \mathrm{Mo}(\mathrm{VI})$. The rotation rate during polarization was $3000 \mathrm{rpm}$. The composition was analyzed with EDS in atomic \% and the relative $\mathrm{Mo} /(\mathrm{Mo}+\mathrm{Ti})$ atomic ratio was in the marked points: a.) $23 \%, b) 26 \%$, c.) $6 \%$, d.) $9 \%$ 


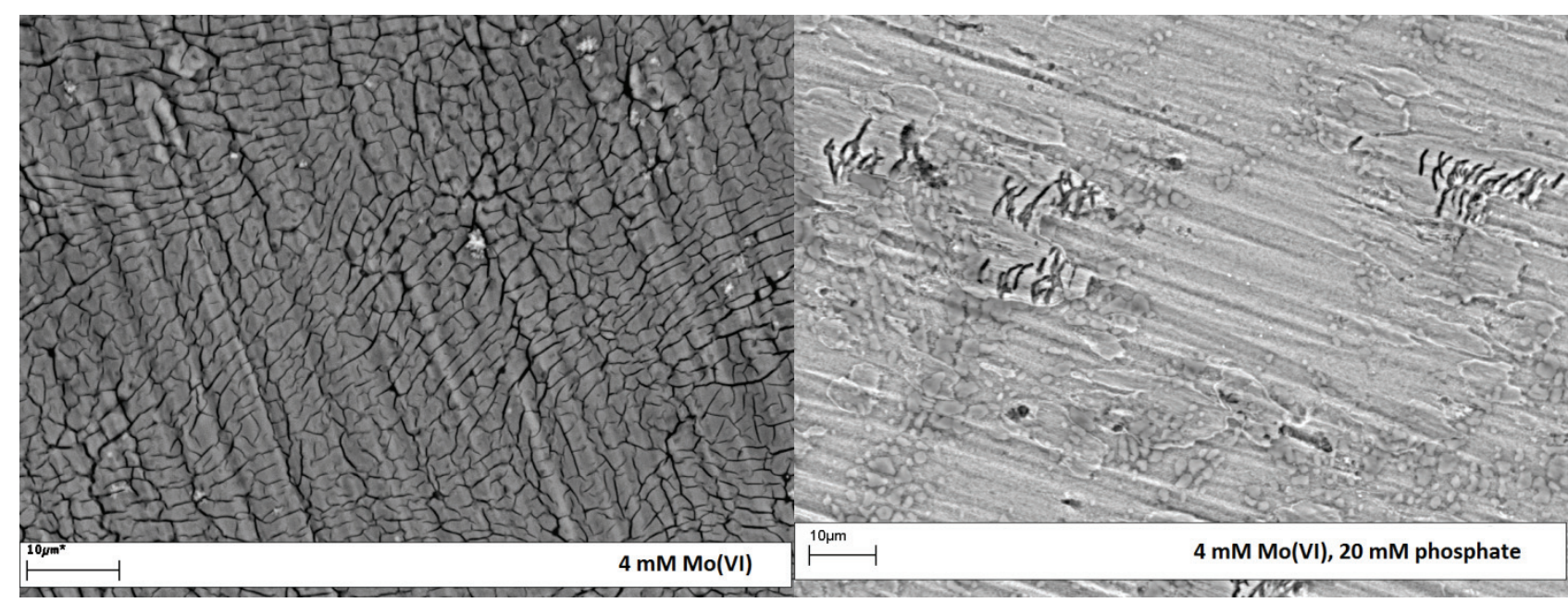

Figure 5. SEM images on Ti-RDEs polarized for $30 \mathrm{~min}$ at $-3 \mathrm{kA} \mathrm{m}^{-2}$ in $2 \mathrm{M} \mathrm{NaCl}, 4 \mathrm{mM} \mathrm{Mo}(\mathrm{VI}), \mathrm{pH} \approx 6.5$ and $70^{\circ} \mathrm{C}$ with and without $20 \mathrm{mM}$ phosphate. The rotation rate during polarization was $3000 \mathrm{rpm}$.

Further surface analyses were performed on titanium cathode samples that had been polarized at $-3 \mathrm{kA} \mathrm{m}^{-2}$ for $30 \mathrm{~min}$ in either $2 \mathrm{M} \mathrm{NaCl}$ at near neutral $\mathrm{pH}$ or in $1 \mathrm{M} \mathrm{NaOH}$, both with addition of $4 \mathrm{mM} \mathrm{Mo}(\mathrm{VI})$. Analyses by means of XRF showed that there was significantly more molybdenum on electrodes polarized in neutral media compared with alkaline electrolyte (Figure 6). The Mo $\mathrm{K}-\mathrm{L}_{3}$ and $\mathrm{K}-\mathrm{M}_{3}$ peaks were in good agreement with data available in open literature [27].

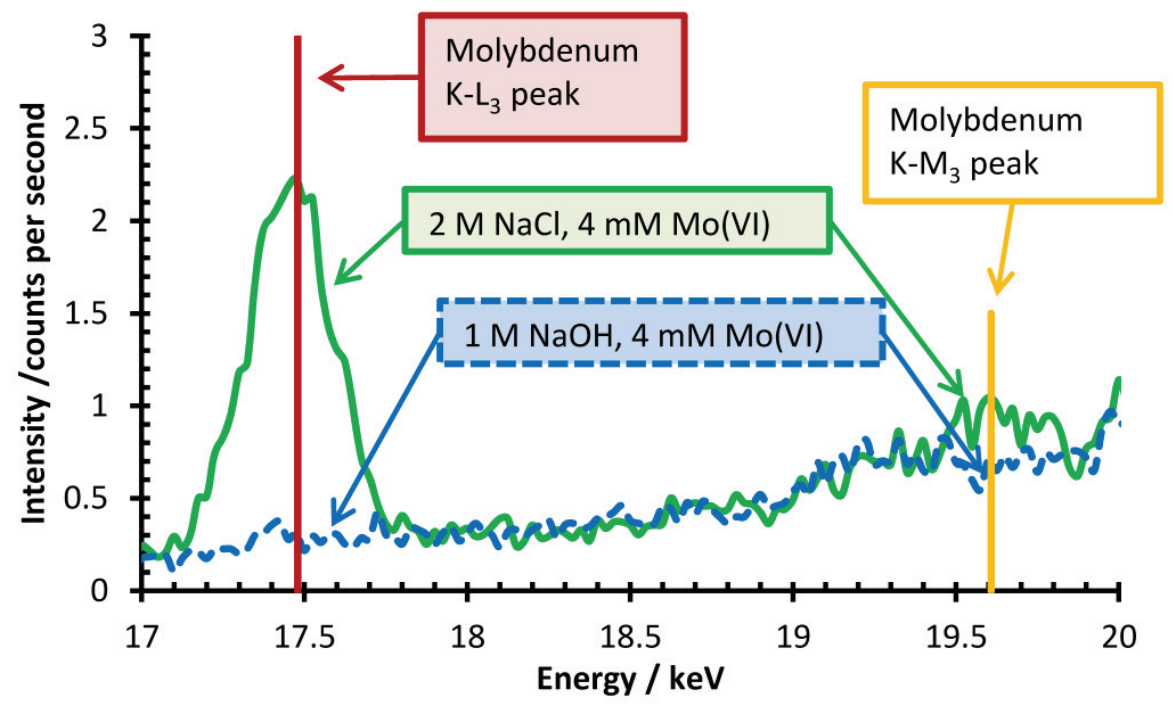

Figure 6. XRF-spectra for Ti-RDEs polarized for $30 \mathrm{~min}$ at $-3 \mathrm{kA} \mathrm{m} \mathrm{m}^{-2}, 70^{\circ} \mathrm{C}$ and a rotation rate of $3000 \mathrm{rpm}$. The $\mathrm{pH}$ was adjusted to 6.5 for the electrolyte containing $2 \mathrm{M} \mathrm{NaCl}, 4 \mathrm{mM} \mathrm{Mo}(\mathrm{VI})$.

XPS analysis shows, in agreement with XRF, a relatively higher intensity of the molybdenum peaks for samples polarized in neutral electrolyte (Figure 7) compared with alkaline electrolyte (Figure 8). Evidently, there was more molybdenum on the sample polarized in neutral electrolyte. The sample polarized in neutral electrolyte displayed XPS spectra which were more complex with several overlapping peaks Mo(3d $\left.\mathrm{d}_{5 / 2}: 229.6 \mathrm{eV} ; 230.7 \mathrm{eV} ; 232.5 \mathrm{eV} ; 233.8 \mathrm{eV} ; 235.0 \mathrm{eV}\right)$, indicating multiple oxidation states of molybdenum. Unambiguous assignments of the peaks were difficult due to overlap between molybdenum oxides and chlorides, and too large variations in reported binding energies also for a given molybdenum oxide, e.g. between 228.3 and $232.7 \mathrm{eV}$ for $\mathrm{MoO}_{2}$ and between 231.6 and $235.6 \mathrm{eV}$ for $\mathrm{MoO}_{3}$ [28]. The sample polarized in alkaline electrolyte revealed only two different oxidation states, of which the predominant $\mathrm{Mo}\left(3 \mathrm{~d}_{5 / 2}\right)$ peak, located at 
$232.6 \mathrm{eV}$, was most probably assigned to $\mathrm{MoO}_{3}$ and the peak at 230.4 to $\mathrm{MoO}_{2}$ [28]. The XPS measurements indicate that the film formed in neutral electrolyte was more complex and probably consisted of polyvalent molybdenum oxides. However, the presence of molybdenum chlorides cannot be excluded. Furthermore, signals from the titanium substrate were only observed when the electrode had been polarized in alkaline electrolyte, indicating that the surface oxide layer was either very thin or formed locally. Relative Mo/Ti atomic ratios determined from XPS were 0.08 and 0.21 as measured in two different areas on the electrode surface. The molybdenum-containing film thus appeared to be formed locally and was unevenly distributed.

XPS measurements also revealed the presence of oxidized iron and copper in the outermost surface of the electrode polarized in $1 \mathrm{M} \mathrm{NaOH}$ with $4 \mathrm{mM} \mathrm{Mo}(\mathrm{VI})$. We suspect that the iron and copper were present as low level impurities in the p.a. sodium hydroxide and that the $30 \mathrm{~min}$ of cathodic polarization was long enough for them to codeposit together with molybdenum on the surface. Iron and molybdenum are known to codeposit [8]-13,15,29,[30] and for example $\mathrm{KOH}$ can contain some iron [8]-[13].

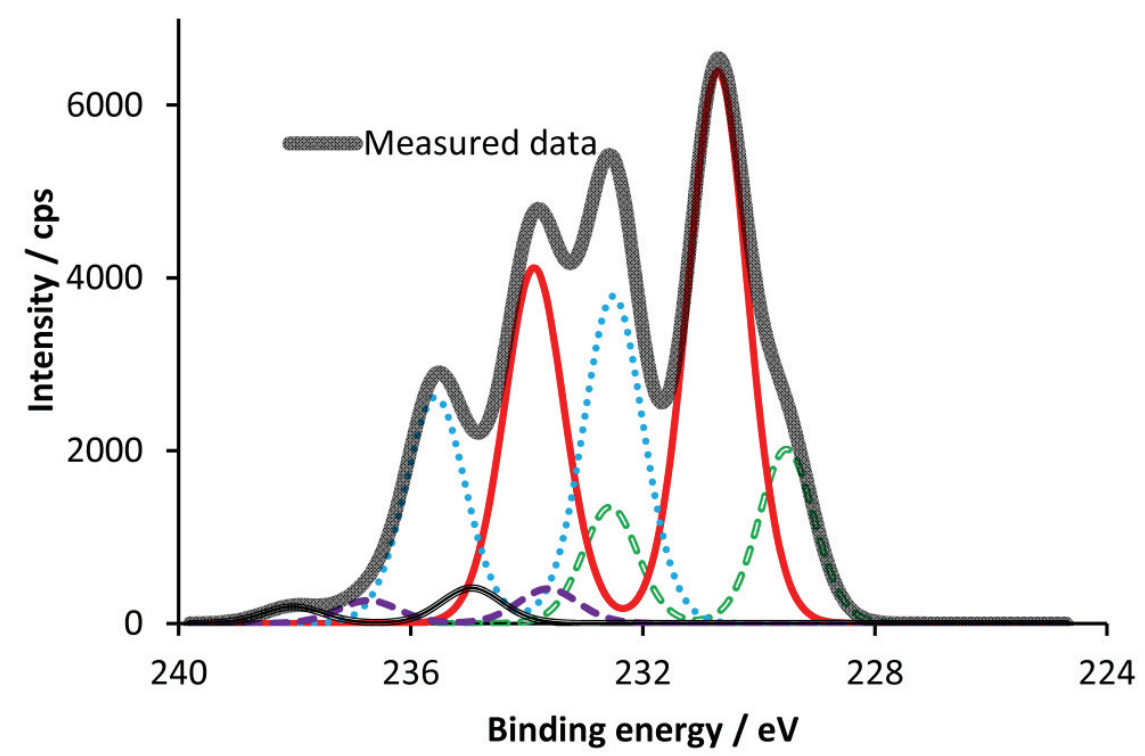

Figure 7. XPS spectrum of the Mo 3d signal with resolved peaks observed in the outermost surface layer of a Ti-RDE polarized for $30 \mathrm{~min}$ in $2 \mathrm{M} \mathrm{NaCl}, 4 \mathrm{mM} \mathrm{Mo}(\mathrm{VI}), p H \approx 7,70^{\circ} \mathrm{C}$ at $-3 \mathrm{KA} \mathrm{m}^{-2}$ and a rotation rate of $3000 \mathrm{rpm}$.

To investigate the molybdenum-iron codeposition, potential-sweep experiments were performed on a platinum rotating disc electrode after $30 \mathrm{~min}$ of pre-polarization at $-3 \mathrm{kA} \mathrm{m}^{-2}$. The results are shown in Figure 9. With added molybdenum, there was an oxidation peak at $-0.65 \mathrm{~V}$, peak 2. Gold and titanium were also used as electrode materials to exclude substrate effects. A similar peak was confirmed on gold and titanium electrodes that had been polarized in $1 \mathrm{M} \mathrm{NaOH}, 4 \mathrm{mM} \mathrm{Mo}(\mathrm{VI}), 70^{\circ} \mathrm{C}$ at $-3 \mathrm{kA} \mathrm{m}^{-2}$ and Au-RDE (Ti-RDE not tested) polarized in $2 \mathrm{M} \mathrm{NaCl}$, $1 \mathrm{M} \mathrm{NaOH}, 4 \mathrm{mM} \mathrm{Mo}(\mathrm{VI}), 70^{\circ} \mathrm{C}$ at $-3 \mathrm{kA} / \mathrm{m}^{2}$. The peak did not appear when the electrolyte was $2 \mathrm{M} \mathrm{NaCl}, 4 \mathrm{mM} \mathrm{Mo}(\mathrm{VI}), \mathrm{pH}$ 7. According to these findings, $\mathrm{pH}$ rather than chlorides affected the appearance of the peak. Considering that on a Pt-RDE when both Fe(III) and Mo(VI) were added to the electrolyte, an even larger peak appeared, it is likely that the peak was connected to the oxidation of an iron-molybdenum deposit. The charge of the oxidation peak corresponds to a film significantly thicker than 10 times the approximately 5-10 nm information depth of XPS. 


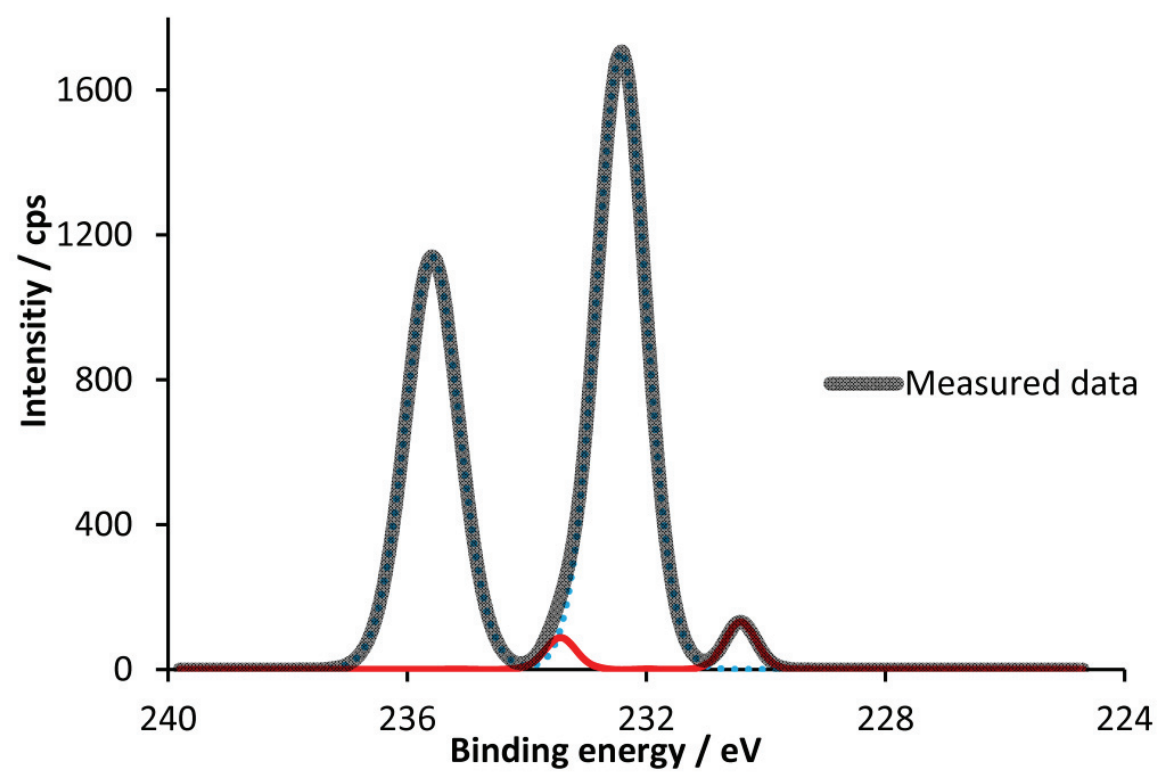

Figure 8. XPS spectrum of the Mo 3d signal with resolved peaks in the outermost surface layer of a Ti-RDE polarized for $30 \mathrm{~min}$ in $1 \mathrm{M} \mathrm{NaOH}, 4 \mathrm{mM} \mathrm{Mo}(\mathrm{VI}), 70^{\circ} \mathrm{C}$ at $-3 \mathrm{kA} \mathrm{m}^{-2}$ and a rotation rate of $3000 \mathrm{rpm}$.

The surface was probably not completely covered by film at the time of XPS analysis since information from the titanium substrate was also observed. When only Fe(III) was added the peak did not appear, again suggesting that the oxidation peak was caused by oxidation of the deposit formed by induced codeposition. A comparison with cyclic voltammograms on iron in $1 \mathrm{M} \mathrm{NaOH}$ at room temperature [31], indicates that Peak 1 at $-0.98 \mathrm{~V}$ may be the oxidation of $\mathrm{Fe}(0)$ to $\mathrm{Fe}(\mathrm{II})$. In $\mathrm{pH}$ neutral electrolytes, the solubility of $\mathrm{Fe}(\mathrm{III})$ is quite low without chelating agents, so it is unlikely that there will be any significant amount of iron and molybdenum codeposition.

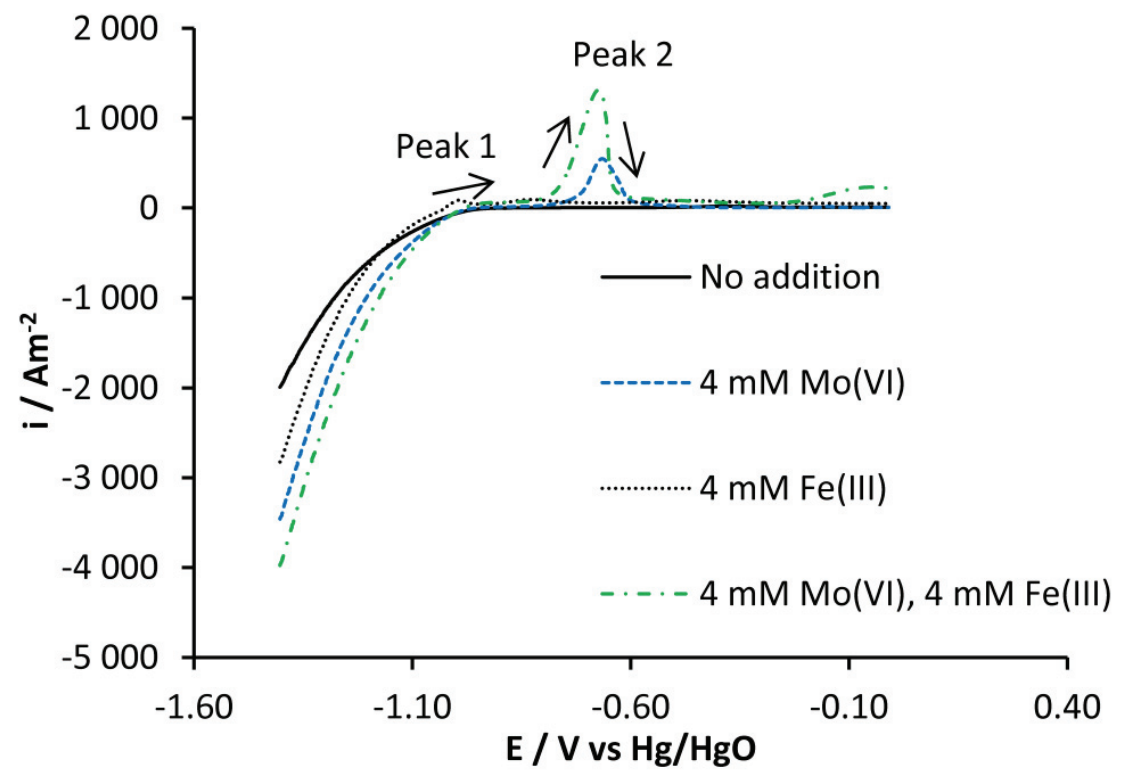

Figure 9. Potential sweeps recorded on a platinum RDE in $1 \mathrm{M} \mathrm{NaOH}, 70^{\circ} \mathrm{C}$ at a sweep rate of $50 \mathrm{mV} \mathrm{s}^{-1}$ and a rotation rate of $5000 \mathrm{rpm}$. The electrode was pre-polarized at $-3 \mathrm{kA} \mathrm{m}^{-2}$ for $30 \mathrm{~min}$ prior to the polarization curves. Concentrations given for Fe(III) correspond to the added amount since some precipitation was observed. 
Thus, the film formed at near neutral $\mathrm{pH}$ contained polyvalent Mo-oxides, whereas the film formed at alkaline conditions was much thinner and contained less molybdenum and a considerable amount of iron impurities. This is consistent with the findings by [8]-[13] and with the limited $\mathrm{pH}$ range of stability of $\mathrm{MoO}_{2}$ [14]4,[16]. Most likely, $\mathrm{MoO}_{2}$ is precipitated in the near neutral electrolyte, whereas in alkaline conditions an Mo-Fe alloy is the obtained deposit.

\section{Combining iron and molybdenum}

As seen in Figure 9 the combination of added $\mathrm{Mo}(\mathrm{VI})$ and $\mathrm{Fe}(\mathrm{III})$ resulted in the largest cathodic currents at negative potentials, which is consistent with an activated HER. Intermetallic phases based on metals from different sides of a volcano plot over the hydrogen binding energy would, according to Brewer-Engel valance bond theory, have a higher activity for HER than the individual metals [31],[33]. Iron and molybdenum are on different sides of the volcano plot and have been codeposited and investigated in the literature for hydrogen evolution activity [9]-[13],[29][30][34]. In all these studies, the alloys were electrodeposited, and thus resulted in films with rough surfaces.

Elezović et al. [34] investigated the activity for HER for Mo-Fe films of varying composition: 34 at.\% (46.9 wt.\%) Mo, 41.8 at.\% (55.2 wt.\%) Mo and 59.2 at.\% (71.4 wt.\%) Mo. The higher the Mo content, the lower the overpotential, but when normalizing with surface roughness factors as determined from double layer capacitances, there was no significant difference between the films. The trend in overpotential between the alloys was therefore mainly attributed to variations in real surface area [34]. In a recent paper [35], a commercial $\mathrm{Fe}_{80} \mathrm{Mo}_{20}$ alloy with a polished surface was used as reference sample when investigating $\mathrm{HER}$ on $\mathrm{Fe}_{75} \mathrm{Mo}_{20} \mathrm{R}_{5}$ ( $\mathrm{R}=\mathrm{Rare}$ earth metal) alloys. Although the Brewer-Engel theory is discussed in both references [34][35], no comparisons were made with the catalytic activity of the pure metals, iron and molybdenum. Both studies were made in $1 \mathrm{M} \mathrm{NaOH}$ at $25^{\circ} \mathrm{C}$.

An alloy was cast to investigate true electrocatalytic effects by alloying Fe and Mo. Rotating disc electrodes, which could be polished to a smooth surface, were prepared to enable comparisons with electrodes of the pure metals without major differences in surface area. As described earlier, the nominal composition of the cast alloy was 72.4 at.\% (60.4 wt.\%) iron and 27.6 at.\% (39.5 wt.\%) molybdenum. Optical microscopy on the alloy showed several phases mixed on the micrometer scale (Figures 10 and 11), and some lighter and darker features. The different features were probably some inhomogeneity of the alloy. The main phases as identified by XRD (Figure 12) were $\mathrm{MoFe}_{2}$ "PDF 04-003-4286" with hexagonal structure, space group P63/mmc (194) and $\mathrm{Mo}_{5.08} \mathrm{Fe}_{7.92}$ "PDF 04-003-7152" with rhombohedral structure, space group $R-3 m$ (166) [21]. There were also some minor phases such as $\mathrm{MoFe}_{2} \mathrm{O}_{4}, \mathrm{MoO}_{3}$ and $\mathrm{Mo}$. Weight fractions of constituents semiquantitatively determined by comparing the integrated intensities of the diffraction peaks from each of the known phases are shown in Figure 12. These data indicates that $\mathrm{Mo}_{5.08} \mathrm{Fe}_{7.92}$ was the most common phase (around $50 \%$ ) in the alloy. To our knowledge, cast iron-molybdenum alloys have not been investigated for HER in neutral electrolytes before. 


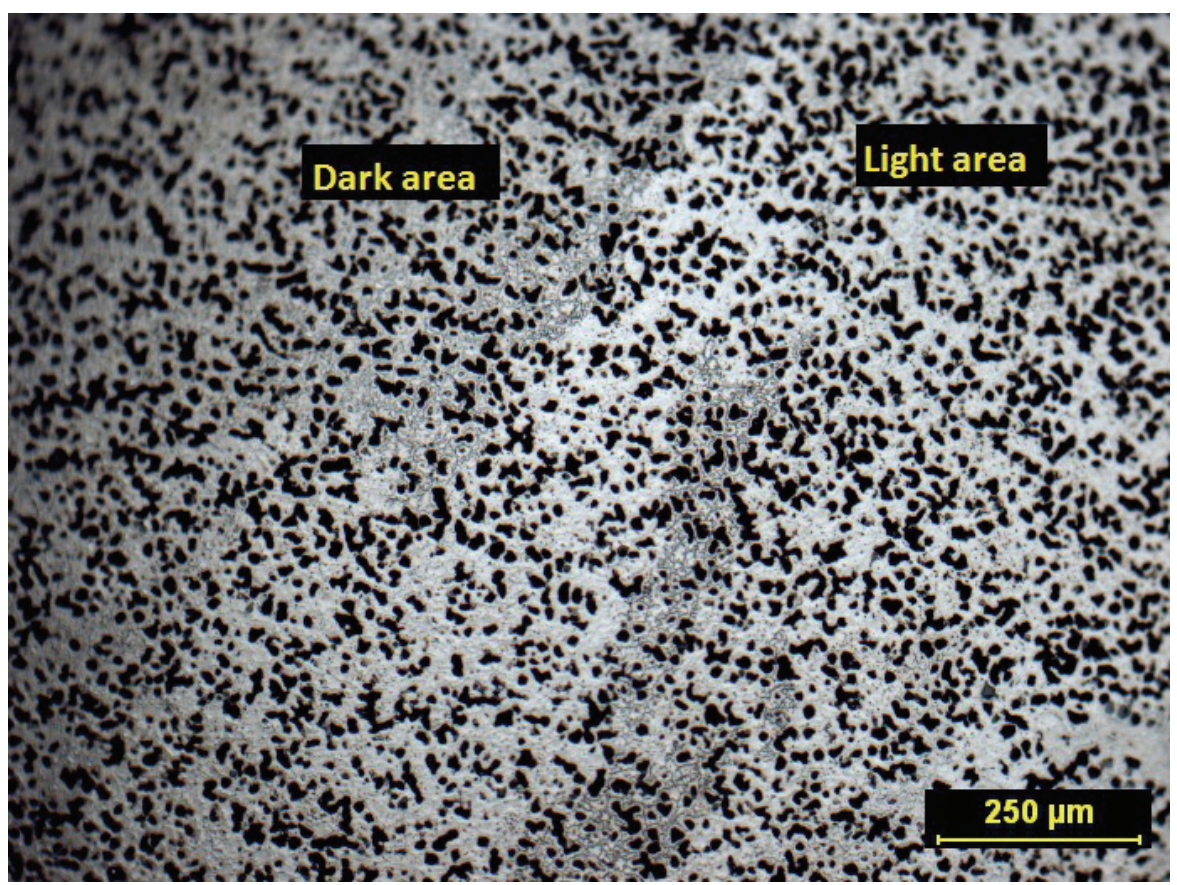

Figure 10. Optical microscopy image of the cast iron-molybdenum alloy.

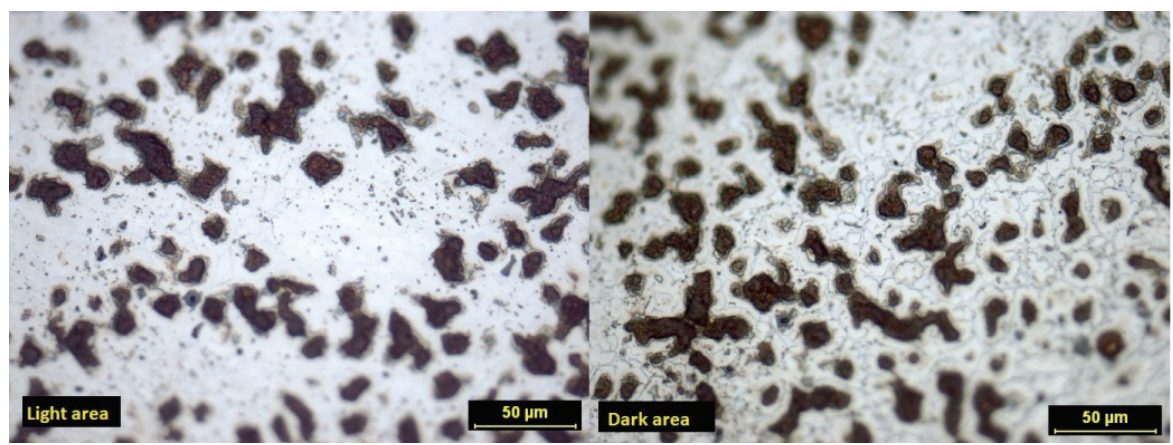

Figure 11. Optical microscopy images of the cast iron-molybdenum alloy. To the left is an image of a lighter area and to the right an image of a darker area on the surface, see Figure 10.

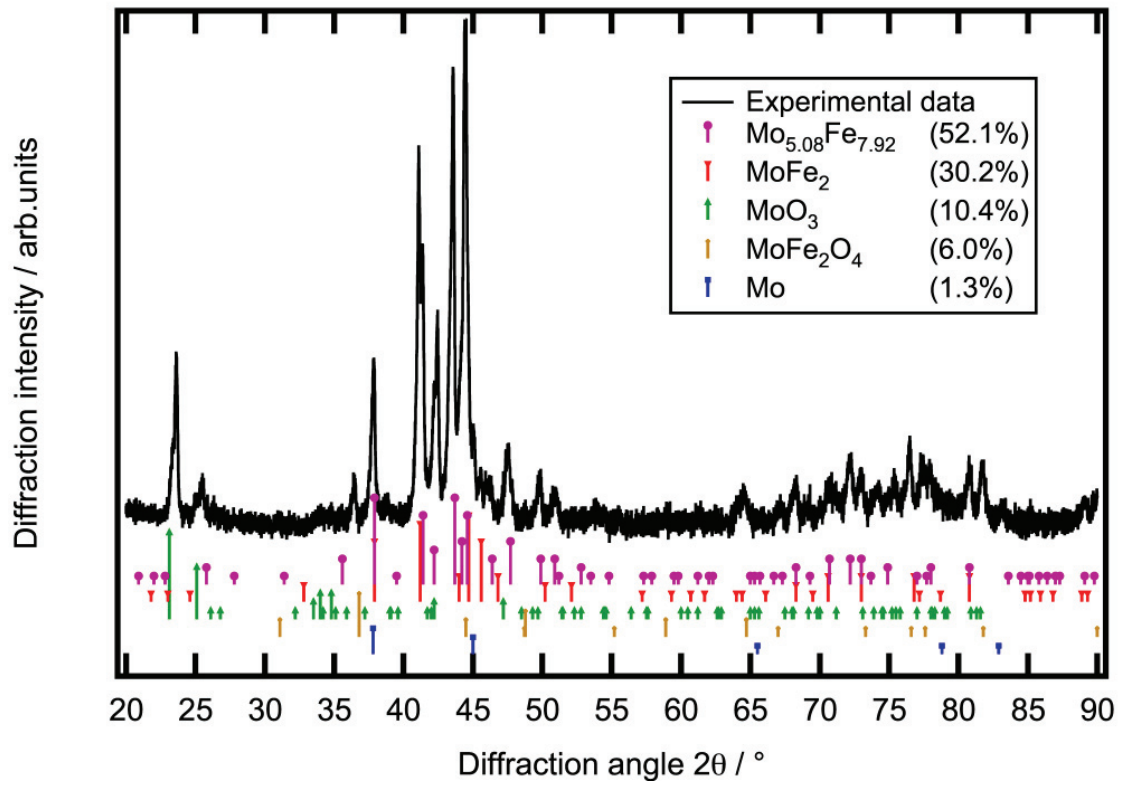

Figure 12. X-ray diffraction pattern of the cast Fe-Mo alloy. The positions of the known diffraction peaks of the identified phases are marked, excluding the peaks with negligible strengths. The percentage numbers in brackets displayed in the legend show the fractions (by mass) determined via the semi-quantitative analysis of the sample composition. 
Polarization curves recorded on Mo-RDE, Fe-RDE and RDE made from the alloy showed that iron and the alloy were both more active for the HER compared with Mo-RDE (Figure 13). The polarization curve of the alloy had a Tafel slope for HER of $-170 \mathrm{mV} \mathrm{dec}{ }^{-1}$. The activity of the alloy for the HER was approximately the same as for pure iron; no synergistic catalytic effect of the alloying could therefore be seen.

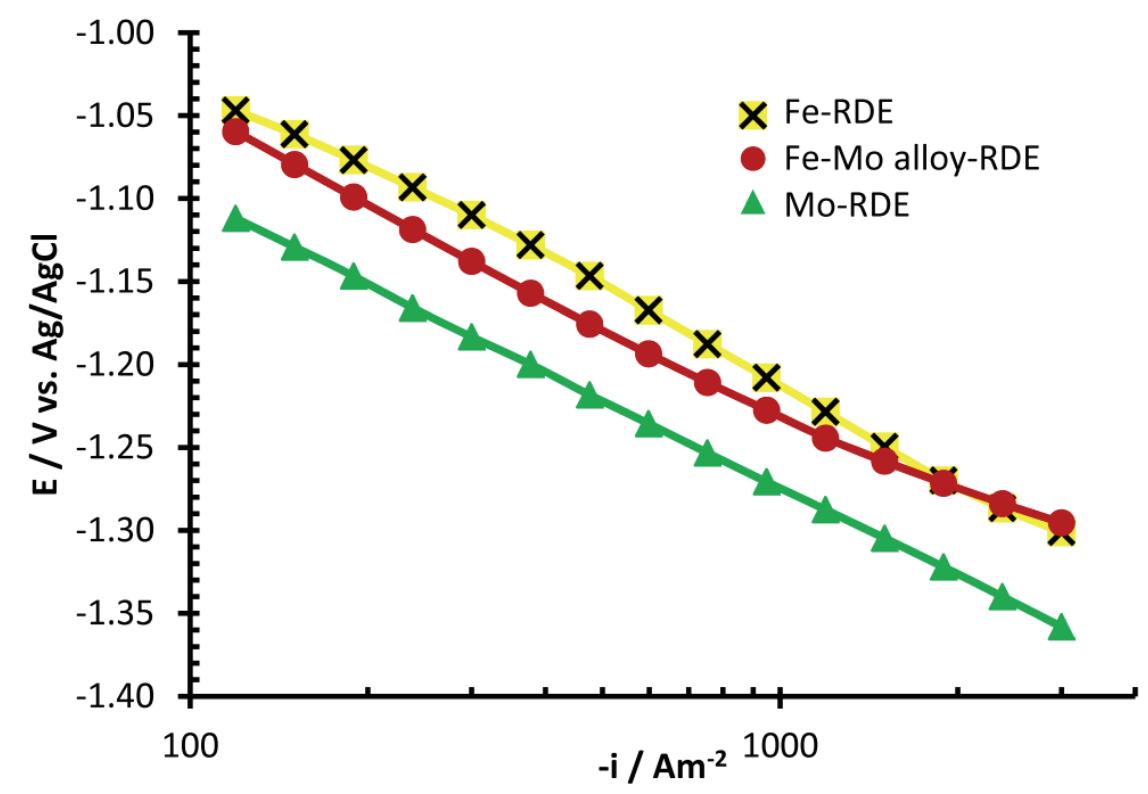

Figure 13. IR-corrected polarization curves recorded in $2 \mathrm{M} \mathrm{NaCl}, p H 6.5,70^{\circ} \mathrm{C}$ at a rotation rate of $5000 \mathrm{rpm}$. All polarization curves were recorded in the anodic direction. The electrodes were pre-polarized at $-3 \mathrm{KA} \mathrm{m}^{-2}$ for 1 min prior to the polarization curves.

\section{Conclusions}

The addition of $\mathrm{Mo}(\mathrm{VI})$ can activate the HER on titanium and molybdenum electrodes in both neutral $\mathrm{NaCl}$ and in alkaline $\mathrm{NaOH}$ electrolytes. In the presence of $\mathrm{Mo}(\mathrm{VI})$, the overpotentials for hydrogen evolution are similar for the two materials in a wide current density range (between -100 and $-3000 \mathrm{kA} \mathrm{m}^{-2}$ ). Cathodic Mo-containing films are formed during polarization, and any electroreduction of $\mathrm{Mo}(\mathrm{VI})$ species does not affect the current efficiency for hydrogen evolution by more than a few percent at most. Films formed at $\mathrm{pH} 6.5$ are active for hydrogen evolution also when transferred to an $\mathrm{Mo}(\mathrm{VI})$-free electrolyte and therefore the mechanism of activation is concluded to originate from a catalytically active film.

At technical current densities in neutral electrolytes, the formed films gave the cathode a similar activity to an iron electrode. It thus seems possible to use a corrosion resistant, robust cathode material in the chlorate process and still get a continuously renewing surface with similar activity as steel cathodes in use today. Phosphate, a possible alternative to chromate for buffering the chlorate electrolyte, does not appear to have any negative effect on this activation at technical current densities. Instead, at a low current density and a good mass-transport, phosphate can further reduce the overpotential for hydrogen evolution.

The cathode films formed during polarization at neutral $\mathrm{pH}$ are much thicker than those formed at alkaline $\mathrm{pH}$. XPS analyses showed that the former have more complex chemical composition, most probably consisting of several polyvalent molybdenum oxides.

The investigated cast alloy of molybdenum and iron was approximately as active as iron for hydrogen evolution. This indicates that electrodeposited iron-molybdenum alloys containing 
$\mathrm{MoFe}_{2}$ and $\mathrm{Mo}_{5.08} \mathrm{Fe}_{7.96}$ will only give a stronger activation of the HER than iron if the real surface area is increased during deposition.

Acknowledgements Grants from Knut and Alice Wallenberg foundation for the XPS instrument are acknowledged. We thank Staffan Palovaara at SCA R\&D Centre AB for helping with the SEM and EDS measurements. Bernth Nordin at Permascand is acknowledged for helping with metallographic specimen preparation. The Swedish Energy Agency, the Swedish Research Council, Permascand, Eka Chemicals and the European Regional Development Fund through the project "EnergyWise" are acknowledged for financing this study.

\section{References}

[1] J. E. Colman, American Inst. Chem. Eng. Symp. Ser. 77 (1981) 244-263

[2] G. Lindbergh and D. Simonsson, J. Electrochem. Soc. 137 (1990) 3094-3099

[3] K. Viswanathan and B. V. Tilak, J. Electrochem. Soc. 131 (1984) 1551-1559

[4] A. Cornell and D. Simonsson, J. Electrochem. Soc. 140 (1993) 3123-3129

[5] L. Roué, M. E. Bonneau, D. Guay, M. Blouin and R. Schulz, J. Appl. Electrochem. 30 (2000) 491-498

[6] M. Li, Z. Twardowski, F. Mok, N. Tam, J. Appl. Electrochem. 37 (2007) 499-504

[7] M. Rosvall, K. Hedenstedt, A. Sellin, J. Gustavsson and A. Cornell, (Akzo Nobel Chemicals International B.V.), WO 2010/130546A1 (2010)

[8] J. Y. Huot and L. Brossard, Int. J. Hydrogen Energ. 12 (1987) 821-830

[9] J. Y. Huot and L. Brossard, Surf. Coat. Tech. 34 (1988) 373-382

[10] J. Y. Huot and L. Brossard, J. Appl. Electrochem. 18 (1988) 815-822

[11] J. Y. Huot and L. Brossard, Int. J. Hydrogen Energ. 14 (1989) 229-232

[12] J. Y. Huot and L. Brossard, J. Appl. Electrochem. 20 (1990) 281-288

[13] L. Brossard and J. Y. Huot, J. Appl. Electrochem. 21 (1991) 508-515

[14] F. J. Presuel-Moreno, M. A. Jakab and J. R. Scully, J. Electrochem. Soc. 152 (2005) B376-B387

[15] A. Brenner, Electrodeposition of Alloys, 1-2, Academic Press Inc., New York, USA, 1963

[16] P. Wang, L. L. Wilson, D. J. Wesolowski, J. Rosenqvist and A. Anderko, Corros. Sci. 52 (2010) 1625-1634

[17] A. Cornell, B. Håkansson, and G. Lindbergh, Electrochim. Acta 48 (2003) 473-481

[18] A. Cornell, G. Lindbergh and D. Simonsson, Electrochim. Acta 37 (1992) 1873-1881

[19] S. Modin and H. Modin, Handbok i metallmikroskopering, Meritförlaget, Johanneshov, Sweden, 1977, p. 366

[20] G. Petzow, Metallographic etching, 2nd ed., ASM International, Materials Park, USA, 1999, p. 86

[21] ICDD (2010). PDF-4+ 2010 (Database), edited by Dr. Soorya Kabekkodu, International Centre for Diffraction Data, Newtown Square, PA, USA

[22] R. Morales, D. U. Sichen and S. Seetharaman I. Arvanitides,, Metall. Mater. Trans. 33B (2002) 589-594

[23] G. Aylward and T. Findlay, SI Chemical Data 4th edition, Jacaranda Wiley Ltd, Milton, Australia, 1998, p. 137

[24] V. Marinović and A. Despić, J. Serbian Chem. Soc. 63 (1998) 545-553

[25] J. Gustavsson, A. Cornell and G. Lindbergh, Int. J. Hydrogen Energy 37 (2012) 9496-9503

[26] S. Goldberg, Soil Sci. 175 (2010) 105-110

[27] J. A. Bearden, Rev. Mod. Phys. 39 (1967) 78-124

[28] R. A. Walton, J. Less Common Met. 54 (1977) 71-80

[29] N.R. Elezović, V.D. Jović, N.V. Krstajić, Electrochim. Acta 50 (2005) 5594-5601 
[30] C. Norman, S. Julia, O. Klaus and R. Glen, (Canexus Chemicals Canada Ltd), WO 2006/039804 A1 (2006)

[31] B. Müller-Zülow, S. Kipp, R. Lacmann and M. A. Schneeweiss, Surf. Sci. 311 (1994) 153-158

[32] M. M. Jakšić, Electrochim. Acta 29 (1984) 1539-1550

[33] M. M. Jakšić, Int. J. Hydrogen Energ. 12 (1987) 727-752

[34] N. R. Elezović, V. D. Jović and N. V. Krstajić, Electrochim. Acta 50 (2005) 5594-5601

[35] F. Rosalbino, D. Macciò, A. Saccone. E. Angelini and S. Delfino, Int. J. Hydrogen Energ. 36 (2011) 1965-1973

(C) 2012 by the authors; licensee IAPC, Zagreb, Croatia. This article is an open-access article distributed under the terms and conditions of the Creative Commons Attribution license (http://creativecommons.org/licenses/by/3.0/) (cc) EY 